DOI 10.31558/2518-7953.2019.1.10

УДК $343.3 / 7$ (477)

P. О. Мовчан

доцент кафедри конституційного, міжнародного і кримінального права Донецького національного університету імені Василя Стуса, канд. юрид. наук, доцент

\title{
ЩОДО АНТИСУСПІЛЬНОЇ СПРЯМОВАНОСТІ САМОВІЛЬНОГО ЗАЙНЯТТЯ ЗЕМЕЛЬНОЇ ДІЛЯНКИ ТА САМОВІЛЬНОГО БУДІВНИЦТВА (СТАТТЯ 197-1 КРИМІНАЛЬНОГО КОДЕКСУ УКРАЇНИ)
}

Ключові слова: самовільне зайняття земельної ділянки, самовільне будівництво, злочини проти власності, злочини проти довкілля, порядок управління.

Згідно з ч. 2 ст. 14 Конституції України право власності на землю гарантується державою, набувається і реалізується громадянами, юридичними особами та державою виключно відповідно до закону.

Тривалий час кримінально-правовою гарантією непорушності вказаних конституційних приписів слугували положення ст. 199 Кримінального кодексу (далі - КК) УРСР (чинного на момент ухвалення Основного Закону нашої держави), якою була передбачена кримінальна відповідальність за самовільне зайняття земельної ділянки та самовільне будівництво. Разом із тим, ухвалюючи КК України від 5 квітня 2001 р., законодавець не знайшов підстав для включення до останнього відповідної норми. Цей невиважений крок Верховної Ради України спровокував масові випадки самовільного зайняття земельних ділянок, значною мірою «розв'язавши руки» тим, хто всупереч закону намагався збагатитися за рахунок незаконного заволодіння землею, але до цього під загрозою настання кримінальної відповідальності уникав таких дій. Підтвердженням сказаного є такі статистичні дані: якщо в 2001 р. було зареєстровано 20680 випадків самовільного зайняття земельних ділянок, то вже у 2006 р. - 41225 таких випадків [1].

Саме тому з метою більш ефективного захисту прав на землю 11 січня 2007 р. держава в особі парламенту відреагувала на відповідні порушення земельного законодавства, ухваливши Закон України «Про внесення змін до деяких законо- 
давчих актів України щодо посилення відповідальності за самовільне зайняття земельної ділянки» і доповнивши КК України ст. 197-1, якою передбачено кримінальну відповідальність за самовільне зайняття земельної ділянки та самовільне будівництво.

Утім, хоча з часу появи зазначеної норми вже минуло понад десять років, у вітчизняній кримінально-правовій доктрині і досі не вщухають дискусії з приводу того, на що ж первинно посягає такий злочин, як «самовільне зайняття земельної ділянки та самовільне будівництво» - на відносини власності, управлінські відносини чи ж довкілля.

Окремі аспекти вказаної проблематики висвітлювались у працях Н. О. Антонюк, Ю. А. Дорохіної, О. Ю. Дрозда, Д. В. Дударця, О. О. Дудорова, В. М. Захарчука, П. С. Матишевського, О. О. Пєнязькової, А. М. Шульги, М. В. Шульги та інших авторів. Однак, попри значний науковий інтерес до цієї тематики, серед криміналістів і нині відсутня єдина позиція щодо вказаного питання.

Наведене вище вказує на актуальність теми иуієі статті, метою якої є формулювання науково обтрунтованих висновків стосовно питання щуодо антисуспільної спрямованості самовільного зайняття земельної ділянки та самовільного будівництва та, відповідно, виправданості розміщення положень щзодо цуього злочину в розділі VI Особливої частини КК України «Злочини проти власності».

У КК УРСР 1960 р. подібна за змістом норма була розміщена у главі IX Особливої частини «Злочини проти порядку управління». Це пояснювалося тим, що в Радянському Союзі земля знаходилась у виключній власності держави. У зв’язку з цим загальновизнаним вважалося положення про те, що «самовільне захоплення землі» посягає на право державної власності на землю і встановлений порядок надання, розподілу та перерозподілу земель; як наслідок, відповідна стаття повинна знаходитися серед злочинів, які посягають на встановлений порядок управління [2, с. 77-79].

Незважаючи на зміну соціально-економічних реалій, деякі сучасні дослідники все рівно продовжують наполягати на тому, що самовільне зайняття земельної ділянки та самовільне будівництво слід відносити до злочинів проти порядку управління, будучи впевненими у тому, що особа при їх вчиненні посягає на порядок управління у сфері земельних і будівельних відносин [3, с. 37-48; 4, с. 26].

Подібним чином розмірковували і автори законопроекту «Про внесення змін до Кримінального і Кримінально-процесуального кодексів України щодо відповідальності за самовільне захоплення земельної ділянки», ухвалення якого врешті-решт і призвело до появи у чинному КК України ст. 197-1. Пропонуючи доповнити КК України статтею 356-1 «Самовільне захоплення земельної ділянки», вони обгрунтовували необхідність такого кроку насамперед потребою вдосконалення системи управління земельними ресурсами, контролю за їх використанням та охороною. 
З урахуванням того, що передбачені ст. 197-1 КК України злочини у певних випадках можуть розглядатись як різновиди самоправства у сфері земельних відносин, у юридичній літературі можна зустріти подібну до попередньої позицію про те, що їхнє місце - серед злочинів проти авторитету органів державної влади та органів місцевого самоврядування, об'єднань громадян та проти журналістів (розділ XV Особливої частини КК України) [5, с. 211; 6, с. 49].

Водночас слід мати на увазі, що після набуття Україною незалежності та скасування монополії права держави на землю поряд із державною власністю виникли інші форми власності на землю. Відповідно до ч. 3 ст. 78 Земельного кодексу (далі - ЗК) України земля в Україні може перебувати у приватній, комунальній та державній власності, а право власності на землю означає традиційну тріаду право володіти, користуватись і розпоряджатися земельними ділянками. При цьому Конституція України (ч. 4 ст. 13), а слідом за нею і Цивільний кодекс (далі ЦК) України (ч. 3 ст. 319) проголосили захист усіх суб’єктів права власності та їхню рівність перед законом.

У зв'язку з цим все більше науковців почало схилятися до думки, що таке суспільно небезпечне діяння, як самовільне зайняття земельної ділянки, має знаходитися саме серед злочинів проти власності, а не проти порядку управління (авторитету органів).

Зокрема, ще в 1996 р. П. С. Матишевський вказував на пов’язані з переходом до ринкової економіки зміни у правовому регулюванні у сфері природних ресурсів і зумовлену цим тенденцію до визнання їх товаром. Вчений висловив передову на той час точку зору про те, що у зв’язку із зруйнуванням монополії держави на землю, що дало можливість громадянам отримати землю у власність, земля стала товаром, і тому самовільне захоплення землі повинно бути віднесено до злочинів проти власності [7, с. 14-16]. Вказаний делікт пропонувалося віднести до другої групи злочинів проти власності, в яку мали бути включені злочини, що полягають у заволодінні земельною, лісовою чи водною ділянкою або набутті права на такі об'єкти шляхом насильства чи обману [8, с. 22].

Вирішуючи питання про сутність самовільного зайняття земельної ділянки, М. В. Шульга характерною рисою цього діяння називає те, що воно завжди спрямоване і безпосередньо пов'язане 3 порушенням належних власнику земельної ділянки правомочностей щодо володіння, користування та розпорядження нею. «У разі самовільного зайняття земельної ділянки порушник або присвоює собі правомочність щодо розпорядження чужою земельною ділянкою, або створює перешкоди власнику щодо розпорядження нею» [9].

Схожі за змістом міркування висловила і Н. О. Антонюк, на думку якої безспірним $є$ те, що, хоча паралельно порушується встановлений у державі порядок законного отримання земельної ділянки, проведення на ній будівництва, первин- 
ним і головним об'єктом самовільного зайняття земельної ділянки як злочинного посягання є саме власність [10, с. 79].

На «антивласницький» характер самовільного зайняття земельної ділянки звертають увагу і чимало інших українських дослідників [11, с. 353; 12, с. 223; 13 , с. $151 ; 14$, с. $64-65 ; 15 ; 16$, с. 660], у т. ч. й фахівці, які досліджували особливості адміністративної відповідальності за аналізоване діяння [17, с. 136; 18, с. 49].

Наприклад, О. Ю. Дрозд висловлюється за виключення з розділу 7 Кодексу України про адміністративні правопорушення (далі - КУпАП) «Адміністративні правопорушення в галузі охорони природи, використання природних ресурсів, охорони пам'яток історії та культури» ст. 53-1 та одночасне доповнення розділу 6 КУпАП «Адміністративні правопорушення, що посягають на власність» ст. 50-1, яка передбачатиме адміністративну відповідальність за самовільне захоплення земельної ділянки. Основним безпосереднім об'єктом вказаного правопорушення автор визнає земельні відносини майнового характеру, що поширюються на власника земельної ділянки з приводу володіння, користування та розпорядження такою ділянкою, а також на законного землекористувача 3 приводу володіння та користування нею [19, с. 196].

Вельми показово, що і в пояснювальній записці до згадуваного вище проекту Закону «Про внесення змін до Кримінального і Кримінально-процесуального кодексів України щодо відповідальності за самовільне захоплення земельної ділянки» зазначалося, зокрема, те, що його ухвалення дасть можливість захистити власників земельних ділянок та землекористувачів від злочинних посягань на земельні ділянки, які перебувають в їх власності чи користуванні, забезпечити реалізацію прав володіння, користування та розпорядження земельними ділянками.

Правильність включення норми про самовільне зайняття земельної ділянки до розділу VI Особливої частини підтверджується й історичним та зарубіжним досвідом кримінально-правової протидії порушенням прав на землю.

Так, починаючи з Руської Правди відповідальність за земельні делікти переважно виступала в якості інструментарію захисту прав власників землі, а самі порушення прав на землю майже на всіх, за винятком радянського, етапах розвитку української державності визнавалися різновидом саме майнових посягань [20, с. 130-134].

Завдяки комплексному аналізу норм не лише кримінального, а й конституційного та земельного законодавства іноземних країн, зокрема, країн так званої «групи СНД», можна переконатися в тому, що самовільне зайняття земельної ділянки розглядається як злочин проти існуючої системи державного управління лише в тих державах, де ще й досі зберігається монополія держави на розпорядження землею (Білорусь, В’єтнам, Таджикистан, Узбекистан). А от у тих країнах, в яких проголошено множинність та рівність усіх форм власності на землю 
(Азербайджан, Казахстан, Киргизія, Молдова), самовільне зайняття земельної ділянки (або інші подібні за змістом діяння) виправдано визнається злочином проти власності [21, с. 172-177]. Слід пам'ятати і про те, що кримінальному законодавству багатьох європейських (і не лише) країн (передусім мова йде про країни французької та італо-іберійської групи романо-германської кримінально-правової системи) також відома відповідальність і за такі різновиди порушень прав на землю, як знищення межових знаків, захоплення чи зайняття земель чи будівель, відхилення русла водойми та насильницьке порушення володіння тощо, які у своій абсолютній більшості також розцінюються як посягання на власність [22, c. $74-104 ; 23$, с. 130-135].

У чинному КК Російської Федерації відсутня спеціальна норма про таке діяння, як самовільне зайняття земельної ділянки. Водночас, виправдовуючи закріплену у ст. 7.1 Кодексу Російської Федерації про адміністративні правопорушення належність самовільного зайняття земельної ділянки до адміністративних деліктів проти власності, О. І. Бойцов звертає увагу на визнання права приватної власності на землю i, внаслідок цього, залучення іiі у цивільний оборот. Науковець переконаний, що земельні ділянки, як і інші відокремлені природні ресурси, можуть визнаватися предметом злочинів проти власності тією мірою, якою їхній оборот допускається законом, що передбачає вільне здійснення власником права володіння, користування і розпорядження такими об'єктами нерухомості [24, c. 141-150]. Інші російські автори стверджують, що незаконне заволодіння земельною ділянкою має розцінюватись як злочин проти власності незалежно від форми власності на цю ділянку $[25$, с. $83 ; 26$, с. $186-187 ; 27$, с. $186 ; 28$, с. $43 ; 29$, c. $18 ; 30$, с. $13-20]$.

На «антивласницьку» спрямованість самовільного зайняття земельної ділянки іноді вказується й у вітчизняній судовій практиці.

Так, розглядаючи матеріали провадження щодо особи-1, котра здійснила самовільне використання земельної ділянки загальною площею 121, 4105 га, суддя Петропавлівського районного суду Дніпропетровської області вказав на те, що основним безпосереднім об'єктом злочину, передбаченого ч. 1 ст. 197-1 КК України, є право власності на землю (право користування землею); правомірна ж управлінська діяльність державних і самоврядних органів у галузі земельних та архітектурно-будівельних відносин виступає лише додатковим об'єктом вказаного злочину [31].

Однак, у юридичній літературі, зокрема, у працях І. Б. Газдайки-Василишин, можна зустріти думку про те, що злочин, передбачений ст. 197-1 КК України, хоча й посягає на відносини власності, але не першочергово, а лише в міру того, що земельні ділянки є об'єктами права власності. Суспільні ж відносини з приводу використання землі (поряд з іншими природними ресурсами) охороняються 
окремим розділом VIII Особливої частини КК України («Злочини проти довкілля»), з огляду на що пропонується ст. 197-1 виключити із розділу VI і доповнити розділ VIII Особливої частини КК статтею 254-1 із аналогічним змістом [32, c. 90-91].

3 ініціативою про перенесення норми про самовільне зайняття земельної ділянки до розділу VIII «Злочини проти довкілля» свого часу виступав i А. М. Шульга, пояснюючи необхідність такого кроку тим, що найголовнішою все ж таки є екологічна функція землі, а всі інші є похідними від неї [33, с. 273].

Утім, відстеживши «механізм» заподіяння шкоди правовідносинам, охоронюваним ст. 197-1 КК України, можна чітко продемонструвати принципову відмінність у характері антисуспільної спрямованості цього посягання та злочинів проти довкілля, зокрема, і інших злочинів у сфері земельних відносин.

Справді, внаслідок вчинення злочинів, передбачених ст. 197-1 КК України, може порушуватися не лише соціальний зв'язок, а й предмет охоронюваних згаданою нормою відносин. Маються на увазі випадки, коли особа, котра самовільно зайняла земельну ділянку, згодом допускає псування, забруднення, нераціональне використання зайнятих земель, незаконне зняття їхнього поверхневого шару тощо. Водночас, на відміну від земельних злочинів «екологічного» характеру (як і переважного числа інших злочинів проти довкілля), вчинення кожного з яких супроводжується обов'язковим впливом на предмет відповідних відносин, що і визначає антисуспільну спрямованість цих посягань, при самовільному зайнятті земельної ділянки шкода предмету може наставати, а може й не наставати (на практиці превалюють саме такі ситуації) - тобто є факультативною.

Таким чином, можна резюмувати, що в переважній більшості випадків самовільне зайняття земельної ділянки не призводить до порушення правовідносин, які охороняються розділом VIII Особливої частини. 3 огляду на це, а також очевидно та принципово відмінний характер порушуваних соціальних зв'язків, не можна ані пристати на зазначені вище пропозиції І. Б. Газдайки-Василишин та А. М. Шульги, ані сприйняти подібні за змістом міркування О. О. Пєнязькової, котра припускає, що видовим об'єктом передбачених чинним кримінальним законодавством земельних злочинів - зокрема, і самовільного зайняття земельних ділянок - слід визнавати порядок суспільних відносин з охорони земель в Україні [6, с. 51].

Розглядаючи теоретичні проблеми кримінально-правової охорони власності в Україні, Ю. А. Дорохіна також дійшла до висновку про необхідність перенесення норми про самовільне зайняття земельної ділянки до розділу VIII Особливої частини [34, с. 396-397].

Між тим, доводиться констатувати, що аргументація, на яку спирається криміналістка при обгрунтуванні ініційованих нею законодавчих змін, є неперекон- 
ливою, адже по суті зводиться лише до того, що «при самовільному зайнятті земельної ділянки порушуються права власника ділянки (а саме право користування), а при самовільному будівництві - лише встановлений державою порядок забудови» [34, с. 114]. Вбачається, що висновок авторки про те, що при самовільному зайнятті земельної ділянки порушуються права власника, не корелюється 3 наступними пропозиціями про перенесення відповідної заборони до злочинів проти довкілля.

Порівняно $з$ попереднім, ще більш спірним залишається питання про оптимальне місцезнаходження норми, в якій передбачено відповідальність за самовільне будівництво на самовільно зайнятій земельній ділянці. Не в останню чергу дискусійність цього питання пояснюється конструюванням чинної редакції ч. 3 ст. 197-1 КК України. Адже з буквального тлумачення диспозиції цієї заборони випливає, що кримінально караним може бути і самовільне будівництво на самовільно зайнятій земельній ділянці, вчинене особою, котра сама не вчиняла самовільне зайняття земельної ділянки. А за таких умов були б підстави констатувати, що цьому делікту, вочевидь, не місце серед злочинів проти власності, адже його основним безпосереднім об'єктом можна було б вважати встановлений порядок будівництва будівель чи споруд на земельній ділянці.

Однак можна припустити, що, встановлюючи кримінальну відповідальність за вчинення самовільного будівництва і пов'язуючи ці дії з самовільним зайняттям земельної ділянки, законодавець перш за все мав на меті захистити право на землю, а тому будівництво на самовільно зайнятій земельній ділянці мало стати звичайною, поруч з іншими, кваліфікуючою ознакою самовільного зайняття земельної ділянки. Якби основним безпосереднім об’єктом злочину, передбаченого ч. 3 ст. 197-1 КК України, справді вважався встановлений порядок будівництва, а не право на землю, то в цій нормі КК України було б вказано лише на самовільне будівництво, без згадування при цьому в ній про самовільне зайняття земельної ділянки. Чинна ж редакція ч. 3 (ч. 4) ст. 197-1 КК України, незважаючи на притаманні їй суттєві вади законодавчої техніки, досить чітко дає зрозуміти, що ключовим у цьому разі є все ж самовільне зайняття земельної ділянки, а самовільне будівництво мало б розумітись як його кваліфікуюча ознака, що нерозривно пов'язана з порушенням прав на землю і свідчить про вищу суспільну небезпеку діяння, позаяк особа, котра його вчинила, ставить себе на місце власника (землекористувача), реалізуючи право останнього на забудову земельної ділянки. Остаточному ж усуненню підгрунтя для дискусії щодо антисуспільної спрямованості діяння, передбаченого ч. 3 (ч. 4) ст. 197-1 КК України, мало б сприяти внесення таких змін до чинної редакції вказаної заборони, які б ще більш чітко продемонстрували «другорядну» роль самовільного будівництва в аналізованому складі злочину, його «залежність» від самовільного зайняття земельної ділянки. 
У будь-якому разі не можна підтримати думку Ю. А. Дорохіної, котра наполягає на тому, що злочини, передбачені ч. 3 та ч. 4 ст. 197-1 КК України, посягають на суспільні відносини у сфері господарювання [34, с. 13]. Пропонуючи подібне трактування, дослідниця не враховує ані юридичну природу відповідного посягання, ані зміст родового об'єкту злочинів, передбачених розділом VII Особливої частини КК України «Злочини у сфері господарської діяльності».

Таким чином, враховуючи положення Конституції України, ЗК Украӥни, ЦК України, думку переважної частини фахівиів, а також історичний (за винятком проміжку часу з 1922 р. до 2001 р.) та зарубіжний досвід регламентаиії кримінальної відповідальності за самовільне зайняття земельної ділянки, можна зробити висновок про те, що включення норми, присвяченої самовільному зайняттю земельної ділянки та будівництву на ній, саме до розділу VI Особливої частини КК Украйни «Злочини проти власності» є обтрунтованим, адже первинно иі діяння посягають саме на відносини власності.

Разом із тим питання щодо основного безпосереднього об'єкту аналізованих злочинів має стати предметом подальших наукових досліджень.

1. Лист Державної інспекції з контролю за використанням та охороною земель від 9 квітня 2009 р. № 5-6-1103/378.

2. Федоров В. Н. Вопросы совершенствования законодательства о самовольном захвате земли. Уголовно-правовая охрана экономической системы СССР : Сборник науч. трудов. М.: Всесоюзный НИИ проблем укрепления законности и правопорядка, 1987. С. 77-79.

3. Дударець Д. В. Самовільне зайняття земельної ділянки і самовільне будівництво за Кримінальним кодексом України: порівняльний аспект, проблеми формулювання та перспективи удосконалення. Судова апеляція. 2009. № 3. С. 37-48.

4. Законодавча реалізація кримінально-правової політики: аналіз законопроектної діяльності Верховної Ради України V скликання 3 питань кримінального права / В. Д. Швець, В. М. Грицак, Я. І. Василькевич, В. О. Гацелюк; вступне слово проф. М. І. Мельника К.: Атіка, 2008. 244 c.

5. Кримінальне право України. Особлива частина: підручник / Ю. В. Александров, О. О. Дудоров, В. А. Клименко та ін.; за ред. М. І. Мельника, В. А. Клименка. К.: Атіка, 2009. 712 с.

6. Пєнязькова О. О. Кримінально-правова охорона земель в Україні: дис. ... канд. юрид. наук. К., 2018. 291 с.

7. Матышевский П. С. Преступления против собственности и смежные с ними преступления. К.: Юринком, 1996. 240 с.

8. Матишевський П. С. К вопросу о кодификации законодательства Украины о преступлениях против собственности. Проблеми юридичної науки та правоохоронної практики. К.: Українська академія внутрішніх справ, 1994. С. 15-25.

9. Шульга М. Самовільне зайняття земельної ділянки. Юридичний вісник України. 2004. 7-13 серпня. № 32 .

10. Антонюк Н. Кримінальна відповідальність за самовільне зайняття земельної ділянки та самовільне будівництво. Вісник прокуратури. 2008. № 1. С. 77-87.

11. Актуальні проблеми кримінально-правової кваліфікації: навч. посіб./ за заг. ред. В. В. Топчія; наук. ред. В. І. Антипова. Вінниця: ТОВ «Нілан-ЛТД», 2017. 896 с. 
12. Бублейник В. А., Терещенко А. І. Кримінально-правова характеристика самовільного зайняття земельної ділянки. Науковий вісник Дніпропетровського державного університету внутрішніх справ. 2008. № 2. С. 221-232.

13. Дякін Я. Класифікація злочинів у сфері земельних відносин. Підприємництво, господарство і право. 2010. № 2. С. 148-151.

14. Захарчук В. М. Самовільне зайняття земельної ділянки та самовільне будівництво за кримінальним правом України: монографія. Хмельницький: Хмельницький університет управління та права, 2015. 214 с.

15. Ковальський Д. Самовільне зайняття ділянки. Юридичний вісник України. 2002. 1925 січня. № 3.

16. Тальянчук I. С. Види та кримінально-правові ознаки злочинів у сфері земельних відносин. Актуальні проблеми держави і права. 2012. Вип. 65. С. 659-668.

17. Вівчаренко О. А. Гарантії права власності на землю в Україні: дис. ... канд. юрид. наук. К., 2005. 199 с.

18. Стукаленко О. В. Адміністративна відповідальність за порушення норм земельного законодавства (матеріальний і процесуальний аспекти): дис. ... канд. юрид. наук. Одеса, 2008. $216 \mathrm{c}$.

19. Дрозд О. Ю. Адміністративна відповідальність за самовільне зайняття земельної ділянки: дис. ... канд. юрид. наук. К., 2010. 273 с.

20. Мовчан Р. О. Регламентація відповідальності за злочини у сфері земельних відносин за Руською Правдою. Протидія злочинності в Україні: кримінально-правові та кримінологічні аспекти: матер. Всеукр. наук.-практ. семінару (м. Миколаїв, 26 травня 2016 р.); упоряд. д-р юрид. наук, доц. С. О. Письменський. Миколаїв: Луган. держ. ун-т внутр. справ ім. Е. О. Дідоренка, 2016. С. 130-134.

21. Мовчан Р. О. Кримінальна відповідальність за порушення прав на землю за законодавством України та країн СНД: порівняльно-правовий аналіз. Jurnalul juridic naţional: teorie şi practică. 2016. № 4. С. 172-177.

22. Мовчан Р. О. Кримінально-правова охорона земельних ресурсів за законодавством країн Західної Свропи. Право і громадянське суспільство. 2015. № 4. С. 74-104.

23. Мовчан Р. О. Кримінально-правова охорона земельних ресурсів за законодавством постсоціалістичних країн Центральної та Східної Свропи. Visegrad Journal on Human Rights. 2016. № 3. С. 130-135.

24. Бойцов А. И. Преступления против собственности. СПб.: Юридический центр Пресс, 2002. 775 c.

25. Самончик О. А. Юридическая ответственность за нарушение земельного законодательства о рациональном использовании и охране земель сельскохозяйственного назначения. Государство и право. 1997. № 2. С. 83-85.

26. Мирзаев 3. М. Пути совершенствования законодательства о регистрации незаконных сделок с землей. Преступность, экономика и организованная преступность. Под ред. д-ра юрид. наук, проф. А. И. Долговой. М.: Российская криминологическая ассоциация, 2007. C. $186-187$.

27. Лопашенко Н. А. Преступления против собственности: теорет.-приклад. исслед. М.: ЛексЭст, 2005. 408 с.

28. Иногамова-Хегай Л., Герасимова Е. Критерии разграничения преступлений против собственности и экологических преступлений. Уголовное право. 2006. № 5. С. 42-45.

29. Ивлева А. Ф. Земельные отношения как объект уголовно-правовой охраны по законодательству Российской Федерации: теоретические и правоприменительные аспекты: автореф. дис. ... канд. юрид. наук. Нижний Новгород, 2007. 31 с.

30. Винокуров В. Причинение имущественного ущерба как критерий признания предметов и информации предметами преступлений против собственности. Уголовное право. 2008. № 4. C. 13-20. 
31. Вирок Петропавлівського районного суду Дніпропетровської області від 26 липня 2018 р. у справі № 188/1672/16-к. Єдиний державний реєстр судових рімень. URL: http://www.reyestr.court.gov.ua/Review/75506395

32. Газдайка-Василишин І. Б. Некорисливі злочини проти власності: монографія. Львів: Львівський державний університет внутрішніх справ, 2012. 212 с.

33. Шульга А. М. Науково-теоретичне визначення видового об'єкту земельних злочинів через земельних правовідносин. Наука кримінального права в системі міждисииплінарних зв 'язків: матеріали міжнар. наук.-практ. конф., 9-10 жовт. 2014 р. / редкол. В. Я. Тацій (голов. ред.), В. І. Борисов (заст. голов. ред.) та ін. Х.: Право, 2014. С. 270-273.

34. Дорохіна Ю. А. Теоретичні проблеми кримінально-правової охорони власності в Україні: дис. ... д-р юрид. наук. Запоріжжя, 2017. 527 с.

DOI 10.31558/2518-7953.2019.1.11

УДК 343.2

\author{
I. \\ доцент кафедри конституційного, \\ міжнародного і кримінального права \\ Донецького національного університету \\ імені Василя Стуса, \\ канд. юрид. наук
}

\title{
УМОВИ ПРАВОМІРНОСТІ, ЩО СТОСУЮТЬСЯ ДІЯННЯ ОСОБИ, ЯКА ЗАЗНАЛА ПРИМУСУ \\ (ЗА ЗМІСТОМ СТАТТІ 40 КРИМІНАЛЬНОГО КОДЕКСУ УКРАЇНИ)
}

Ключові слова: примус, обставини, щзо виключають злочинність діяння, діяння особи, яка зазнала примусу, крайня необхідність, обмежена осудність, свобода волі, насильство.

Дослідження обставин, що виключають злочинність діяння, займає важливе місце в науці кримінального права. Традиційно більше уваги приділяється необхідній обороні та крайній необхідності, окреме опрацювання отримали проблеми затримання особи, що вчинила злочин, виконання наказу або розпорядження та виправданого ризику. Водночас наукові проблеми фізичного або психічного примусу як обставини, що виключає злочинність діяння, у кримінально-правовій доктрині висвітлені не повною мірою.

Різні аспекти підстав вчинення діяння у стані фізичного або психічного примусу раніше розглядались у наукових працях Ю. В. Бауліна [1], В. А. Бліннікова [2], О. В. Дегай [3], А. О. Касьяна [4], С. Г. Келиної [5], В. Ю. Рунова [6], Є. Л. Стрельцова [7] та інших авторів. Проте ряд проблемних питань, які вини- 